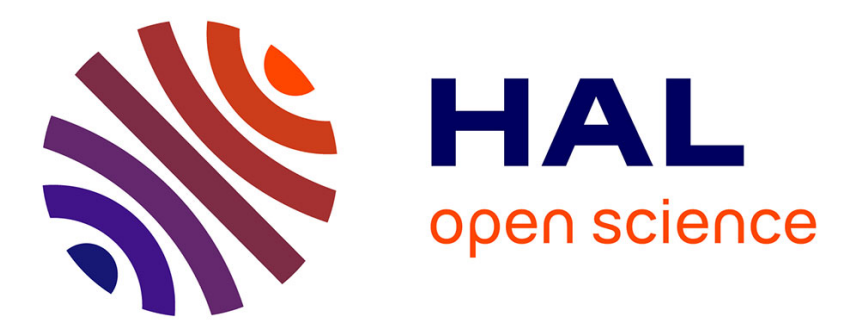

\title{
Nitrogen addition to the canopy of Castanopsis chinensis (Sprengel) Hance promoted xylem formation in a subtropical forest in China
}

Xiali Guo, Jian-Guo Huang, Jingye Li, Hanxue Liang, Biyun Yu, Qianqian Ma, Shaowei Jiang, Xiankai Lu, Shenglei Fu, Qing Ye, et al.

\section{To cite this version:}

Xiali Guo, Jian-Guo Huang, Jingye Li, Hanxue Liang, Biyun Yu, et al.. Nitrogen addition to the canopy of Castanopsis chinensis (Sprengel) Hance promoted xylem formation in a subtropical forest in China. Annals of Forest Science, 2020, 77 (2), pp.56. 10.1007/s13595-020-00962-0 . hal-03259262

\section{HAL Id: hal-03259262 https://hal.science/hal-03259262}

Submitted on 14 Jun 2021

HAL is a multi-disciplinary open access archive for the deposit and dissemination of scientific research documents, whether they are published or not. The documents may come from teaching and research institutions in France or abroad, or from public or private research centers.
L'archive ouverte pluridisciplinaire $\mathbf{H A L}$, est destinée au dépôt et à la diffusion de documents scientifiques de niveau recherche, publiés ou non, émanant des établissements d'enseignement et de recherche français ou étrangers, des laboratoires publics ou privés. 


\title{
Nitrogen addition to the canopy of Castanopsis chinensis (Sprengel) Hance promoted xylem formation in a subtropical forest in China
}

\author{
Xiali Guo ${ }^{1,2,3,4}$. Jian-Guo Huang ${ }^{1,2,3} \cdot$ Jingye $\mathrm{Li}^{1,2,3,4} \cdot$ Hanxue Liang ${ }^{1,2,3} \cdot$ Biyun Yu ${ }^{1,2,3,4} \cdot$ Qianqian Ma ${ }^{1,2,3}$. \\ Shaowei Jiang ${ }^{1,2,3,4} \cdot$ Xiankai $\mathrm{Lu}^{1,2,3} \cdot$ Shenglei $\mathrm{Fu}^{5} \cdot$ Qing $\mathrm{Ye}^{1,2} \cdot$ Ping Zhao $^{1,2,3} \cdot$ Xian Cai $^{1,2,3}$
}

Received: 27 September 2019 / Accepted: 15 May 2020 / Published online: 11 June 2020

(C) INRAE and Springer-Verlag France SAS, part of Springer Nature 2020

\begin{abstract}
- Key message Nitrogen addition during 4 years to the canopy of Castanopsis chinensis (Sprengel) Hance promoted xylem formation, mainly by increasing radial growth during the early growth season.

- Context Increased atmospheric nitrogen $(\mathrm{N})$ deposition caused by intensive anthropogenic activities resulted in inconsistent effects on the xylem formation of trees, in N-limited boreal and temperate forests. However, the effects of $\mathrm{N}$ deposition on xylem formation of trees in subtropical forests are still poorly understood.

- Aims The aims of the study were to (i) characterize the dynamics of xylem formation in C. chinensis in a subtropical forest in China and (ii) determine the effect on xylem formation of adding $\mathrm{N}$ to the canopy.

- Methods From 2013 to 2016, $50 \mathrm{~kg} \mathrm{~N} \mathrm{ha}^{-1}$ year $^{-1}$ was applied over the canopy of $C$. chinensis at the end of each month (April to October) in a subtropical forest in southern China. Then, the dynamics of xylem formation were monitored during 2015 and 2016 using a microcore sampling approach.

- Results Xylem formation of C. chinensis lasted from February to December and the growth rate peaked during April-May. Adding $\mathrm{N}$ to the canopy promoted xylem width, by $21 \%$ in 2015 and $20 \%$ in 2016 , mainly by increasing the growth rate during the early growth season (February to May in 2015 and February to April in 2016).

- Conclusion Our study suggests that in a subtropical forest, canopy N addition could significantly promote the xylem ring width of $C$. chinensis. However, the response of tree growth to $\mathrm{N}$ addition showed significant difference between the early and late growth season. Therefore, further studies are needed to more comprehensively address the effect of $\mathrm{N}$ deposition on tree growth under global climate change.
\end{abstract}

Keywords Nitrogen deposition · Broad leaf species · Wood formation · Growth rate · Carbon sink

Xiali Guo, Jian-Guo Huang and Jingye Li contributed equally to this work.

Xiali Guo, Jian-Guo Huang, and Jingye Li are co-first authors.

Handling Editor: Cyrille B. K. Rathgeber

Contributions of the co-authors JGH, SLF, QY, PZ, XAC, and XKL designed the study; XLG conducted the field and lab work; XLG, HXL, BYY, QQM, and SWJ analyzed the data; and XLG, JGH, and JYL wrote the manuscript.

Jian-Guo Huang

huangjg@scbg.ac.cn

Extended author information available on the last page of the article

\section{Introduction}

Deposition of atmospheric nitrogen $(\mathrm{N})$ induced by intensive human activities, including fuel combustion and fertilization, has altered the $\mathrm{N}$ cycle on a global scale (Galloway et al. 2004). Although a moderate amount of $\mathrm{N}$ addition is beneficial to plant growth, excessive $\mathrm{N}$ deposition may lead to soil acidification (Lu et al. 2014) and decreased biodiversity (Sala et al. 2000; Bobbink et al. 2010; Lu et al. 2011), which alter the structure and function of forest ecosystems by changing their species compositions (Liu et al. 2018). Therefore, it is critical to understand the effects of $\mathrm{N}$ deposition on tree growth in subtropical forests, which have been reported to be major regional carbon sinks (Yu et al. 2014).

In southern China, the rate of natural atmospheric deposition is $30-73 \mathrm{~kg} \mathrm{~N} \mathrm{ha}^{-1}$ year $^{-1}$ (Huang et al. 2012), which is 
close to the maximum value of $\mathrm{N}$ deposition rate in Europe (MacDonald et al. 2002). A trend of increasing $\mathrm{N}$ deposition is expected in the coming decades (Galloway et al. 2008; Liu et al. 2013). When the availability of $N$ surpasses the biotic demand, ecosystems are considered to be N-saturated, meaning that no additional $\mathrm{N}$ will be retained (Aber 1992). Previous studies have demonstrated that the soil systems in subtropical forests were $\mathrm{N}$-saturated, due to the large amounts of $\mathrm{N}$ leaching loss from soil (Mo et al. 2006; Fang et al. 2009; Lu et al. 2014). Compared with soil systems, plants have a more flexible ability to retain and use increased $\mathrm{N}$ deposition ( $\mathrm{Lu}$ et al. 2018). For example, Yu et al. (2019) found inconsistent responses of the stem growth to $\mathrm{N}$ in Quercus acutissima Carruth and Quercus variabilis Blume. Another $\mathrm{N}$ addition over a year (30 $\mathrm{g} \mathrm{N} \mathrm{m}^{-2}$ year $\left.^{-1}\right)$ significantly reduced the height and stem-base diameter, biomass production, and net photosynthetic rate of Schima superba Gardn. et Champ and Cryptocarya concinna Hance in a subtropical forest in south China (Mo et al. 2008). This shows that a consensus on the effects of $\mathrm{N}$ deposition on tree growth has not been reached yet.

Annual ring width depends on the growth rate of xylem and the actual length of the growth season (Rathgeber et al. 2011). More $\mathrm{N}$ could significantly promote photosynthesis, thus providing additional energy critical for xylem formation (Nakaji et al. 2001; Bauer et al. 2004). The dynamics of xylem formation can reflect the current $\mathrm{N}$ status and can be used to assess the effect of $\mathrm{N}$ deposition on tree growth and forest ecosystems. For example, $\mathrm{N}$ can enhance the xylem width of Pinus cembra at the alpine treeline without changing the xylem formation phenology (Gruber et al. 2018). In N-limited boreal forests, short-term manipulative experiments have also shown that adding $\mathrm{N}$ has no significant effect on the timing of xylem cell development (Lupi et al. 2012; D’Orangeville et al. 2013; Dao et al. 2015). In a temperate forest, a 3-year $\mathrm{N}$ addition did not evidence any difference in neither the xylem phenology nor the cell production of Pinus massoniana Lamb and Liquidambar formosana (Zhang et al. 2017, 2018). However, as N-manipulation experiments have mainly been conducted in temperate and boreal forests, it remains unclear how wood formation dynamics respond to $\mathrm{N}$ deposition in subtropical forests.

Traditional N-manipulation experiments usually add $\mathrm{N}$ to the understory, neglecting the complex effect of $\mathrm{N}$ interception in the canopy (Rose 1996; Dail et al. 2009). As they do not realistically simulate natural $\mathrm{N}$ deposition, the conventional $\mathrm{N}$ experiments might underestimate the effect of adding $\mathrm{N}$ (Zhang et al. 2015). In fact, $\mathrm{N}$ retention in the canopy has been shown to be a critical process in the $\mathrm{N}$ cycle of forest ecosystems (Dail et al. 2009). Depending on the forest type and background amount of $\mathrm{N}, 1-70 \%$ of the $\mathrm{N}$ added may be absorbed directly by leaves, epiphytes, and micro-organisms and then enter various chemical circuits in a forest's upper layer (Lovett and Lindberg, 1993; Gaige et al. 2007; Adriaenssens et al. 2012), which directly or indirectly affects xylem formation and subsequently tree growth. Therefore, addition of $\mathrm{N}$ to the canopy probably is a more reliable approach to estimate the actual effects of atmospheric $\mathrm{N}$ deposition on forest ecosystems (Zhang et al. 2015).

From 2013 to $2016,50 \mathrm{~kg} \mathrm{~N}^{-1}$ year $^{-1}$ was applied over the canopy of study sites at the end of each month (April to October), with a dose of $7.14 \mathrm{~kg} \mathrm{~N}^{-1}$ per month. The effect of these repeated applications on the dynamics of xylem formation were assessed in Castanopsis chinensis (Sprengel) Hance in a subtropical forest in China. The recently developed microcore sampling approach, which has been increasingly applied in the fields of tree physiology and forest ecology (Deslauriers et al. 2003; Rossi et al. 2006; Huang et al. 2018), was used to monitor the weekly wood formation of C. chinensis during the growth season of 2015 and 2016. C. chinensis is a ring-porous species widely distributed in southern China, and the growth dynamics affected by nitrogen deposition could further influence forest structure by altering interspecies competition. The aims of the present study were to (i) characterize the dynamics of xylem formation in $C$. chinensis in a subtropical forest in China and (ii) determine the effect on xylem formation of adding $\mathrm{N}$ to the canopy.

\section{Materials and methods}

\subsection{Study site}

This study was conducted in the Shimentai National Natural Reserve (SMT, 24 23' 53" N, $113^{\circ} 11^{\prime} 56^{\prime \prime}$ E), in Guangdong Province in south China. This site belongs to a climate zone that is transitional between the midtropical and subtropical zones in the East Asia monsoon region. From 1984 to 2014, the average annual temperature was $20.5{ }^{\circ} \mathrm{C}$, and the average monthly temperatures in January and July were $10.9{ }^{\circ} \mathrm{C}$ and $28.3^{\circ} \mathrm{C}$, respectively. The mean annual precipitation was $1780 \mathrm{~mm}$, with $76 \%$ falling during the wet season (April to September). This forest is dominated by evergreen broadleaf species, including $C$. chinensis, Ardisia quinquegona BL., S. superba, C. concinna, Machilus chinensis (Champ. ex Benth.) Hemsl., Engelhardia roxburghiana Wall., etc. (Zhang et al. 2015). In July 2012, the forest was examined for trees that had a diameter at breast height $(\mathrm{DBH}) \geq 10$ $\mathrm{cm}$. The stand density was about 818 tree $\mathrm{ha}^{-1}$, and the mean tree $\mathrm{DBH}$ and tree height were $18.6 \mathrm{~cm}$ and $13.8 \mathrm{~m}$, 
respectively. The soil type in this region is latosolic red and has a pH ranging from 5.0 to 5.5 (Zhang et al. 2015).

\subsection{Experimental design}

In 2013, 2 circular areas with radii of $17 \mathrm{~m}$ were labeled, respectively. In the center of the $\mathrm{N}$ addition site $(\mathrm{CN})$, a spraying system for adding $\mathrm{N}$ was installed, while the other site was untreated (CK). To mimic natural, gradually deposited $\mathrm{N}, \mathrm{NH}_{4} \mathrm{NO}_{3}$ solution was applied to the forest canopy at the end of each month (from April to October), with a dose of $7.14 \mathrm{~kg} \mathrm{~N} \mathrm{ha}^{-1}$ per month (Zhang et al. 2015). On windless days, $\mathrm{N}$ solution can be applied evenly to the canopy of the dominant trees. The $\mathrm{N}$ addition system included five components: a tank for storing $\mathrm{N}$ solution, connecting pipes, a supporting tower, four sprinklers, and a computer for central control. A tank with a capacity of 20 $\mathrm{m}^{3}$ was built to store the $\mathrm{N}$ solution on the uphill side of the experimental site and was connected with various PVC pipes $(7.5 \mathrm{~cm}$ inner diameter) to transport the $\mathrm{N}$ solution to the top of the supporting tower. This tower was $35 \mathrm{~m}$ high, made of galvanized steel, and had a strong concrete base $(200 \mathrm{~cm} \times 200 \mathrm{~cm} \times 200 \mathrm{~cm})$ to support the PVC pipes and 4 crane sprinklers. To quantify the actual amount of the solution used, flow meters and pressure gauges were installed at the ends of the pipes. The 4 sprinklers, which had varying spraying ranges, were installed on the top of the tower, which was $5 \mathrm{~m}$ above the canopy. The sprinklers could turn $360^{\circ}$ and spray the $\mathrm{N}$ solution as far as $17 \mathrm{~m}$, depending upon the pressure used. All technical parameters were set and controlled using a central computer. To avoid soil contamination, at least $20 \mathrm{~m}$ of uncontaminated, undisturbed buffer zone was set around each treatment site. Trees in the N-treated area received an additional $21 \mathrm{~mm}$ of solution per year, which contributed $<1 \%$ of the total annual precipitation at the study site. Therefore, the disturbing effect of the additional solution could be ignored (Zhang et al. 2015). The $\mathrm{N}$ added to the forest canopy was $50 \mathrm{~kg} \mathrm{~N} \mathrm{ha}^{-1}$ year $^{-1}$, which is significantly higher than the background rate of $\mathrm{N}$ deposition $\left(34.1 \mathrm{~kg} \mathrm{~N} \mathrm{ha}^{-1}\right.$ year $^{-1}$ ) (Zhang et al. 2015).

Table 1 Characteristics of $C$. chinensis in the monitored trees by treatment in Shimentai National Reserve. DBH represents diameter at the breast height. $\mathrm{CK}$ and $\mathrm{CN}$ represent control and $\mathrm{N}$-treated trees

\begin{tabular}{llll}
\hline Treatment & DBH $(\mathrm{cm})$ & Height $(\mathrm{m})$ & Crown length $(\mathrm{m})$ \\
\hline $\mathrm{CK}$ & $22.1 \pm 7.0$ & $12.9 \pm 4.1$ & $9.7 \pm 3.3$ \\
$\mathrm{CN}$ & $21.0 \pm 4.1$ & $15.5 \pm 3.1$ & $8.6 \pm 5.2$ \\
\hline
\end{tabular}

\subsection{Monitoring the formation of wood}

For each treatment, four healthy, mature trees were randomly chosen to monitor xylem formation (Guo et al. 2020). Table 1 shows the DBH, height, and crown length of all the $C$. chinensis in the treatment. At the beginning of the study, 2 increment cores, each $5.1 \mathrm{~mm}$ in diameter, were collected from the selected trees, and the widths of the rings in these cores were measured using a Velmex measuring system and the Time Series Analysis Program (TSAP). All the trees showed similar growth between 2010 and 2013 (before the beginning of the $\mathrm{N}$ addition experiment). Each week in 2015 and 2016, a microcore $(2 \mathrm{~mm}$ in diameter and $2-3 \mathrm{~cm}$ in length) was extracted from the tree stems at breast height using a Trephor (Rossi et al. 2006), for a total of 760 microcores. To avoid any disturbances from nearby sampling points, each microcore was taken at a point that was at least $5 \mathrm{~cm}$ from any other. After sampling, the microcores were placed in Eppendorf microtubes containing a solution of $50 \%$ ethanol and stored at $4{ }^{\circ} \mathrm{C}$ until analysis, at which point the microcores were dehydrated using ethanol solution and pure D-limonene successively and then embedded in paraffin. Next, transverse sections $8 \mu \mathrm{m}$ long were cut using a Leica RM2235 rotary microtome. Then, the paraffin was removed using D-limonene, and the sections were stained using $0.6 \%$ cresyl violet acetate and examined under a microscope to identify the cambium and xylem cells at various stages of development (Deslauriers et al. 2003; Rossi et al. 2006). The cambium cells were characterized by their smaller radial diameters compared to the enlarging cells. Due to the existence of the secondary wall in the wall-thickening cells and the mature cells, birefringence was observed under polarized light (Abe et al. 1997). The wallthickening cells and the mature cells were identified by their color changes from violet to blue and homogeneous blue, respectively (Gricar et al. 2005). Finally, the widths of the cell layers in the cambium and the zones containing the enlarging cells, wall-thickening cells, and mature cells were measured along three radial files, and the width of the xylem ring (i.e., the sum of the widths of the zones with the enlarging cells, wall-thickening cells, and mature cells) was also calculated. In this study, the day of the appearance of first enlarging cells and last enlarging cells of each tree were identified as the start and end of growth season of each tree, respectively. Given the variance among trees, we calculated an average date for the beginning and end of the growth seasons for the trees in both treatment areas in both 2015 and 2016. 


\subsection{Curve fitting and statistics of xylem formation}

The xylem increments measured during the growth season of each tree were modeled using the Gompertz function, which is defined as:

$y=A \exp \left[-e^{(\beta-k t)}\right]$

where $y$ stands for weekly xylem formation, and the parameters $A, \beta$, and $k$ represent the upper asymptote, the $x$-axis placement, and the change rate of the curve, respectively. In addition, the day of maximum growth rate $\left(T_{\mathrm{p}}=\beta / k\right)$ was also calculated. To investigate if the effect of $\mathrm{N}$ addition on xylem formation differs during early and late season, the growth season was subdivided into early and late growth season. That is, the period during the onset of xylem production and the $T_{\mathrm{p}}$ was identified as the early growth season, and the period during the $T_{\mathrm{p}}$ and the end of the growth season was identified as the late growth season. Repeated measures analysis of variance (ANOVA) using day of the year (DOY) as a repeated factor was applied to explore the effect of $\mathrm{N}$ addition on the xylem production, growth rate, and width of the cambial zone and the differentiating xylem cells during both the early and late growth seasons. All statistical analyses were performed using $\mathrm{R}$ 3.4.2 (R Core Team 2018), and all diagrams were created using Sigma Plot 13.0.

\section{Results}

\subsection{Dynamics of intra-annual wood formation}

As Fig. 1 shows, cambial cells and differentiating xylem cells displayed similar growth patterns in $\mathrm{CK}$ and $\mathrm{CN}$ trees in 2015 and 2016. The width of the cambial zone showed an indistinct annual pattern, with a single peak between DOY 150 and DOY 200 in both years (Fig. 1a). The enlarging cells first appeared in February in 2015 and 2016, and the width of the zone with enlarging cells fluctuated at about $50 \mu \mathrm{m}$ between April and October (Fig. 1b). The width of the zone with wallthickening cells fluctuated slightly during February and March (DOY 34-100). After that, it increased sharply and then decreased slowly until the end of December (Fig. 1c). The width of the zone with mature cells increased rapidly from DOY 100 to 150 and then varied greatly until the late growth season in December (Fig. 1d). The average onset of xylem formation was at DOY 32 in 2015 and DOY 45 in 2016. The average end of xylem formation was at DOY 356 in 2015 and DOY 364 in 2016. Therefore, February and December were identified as the onset of the growth season and as its end, respectively. After the onset of xylem formation in February, the rate of xylem formation in all trees increased rapidly and peaked in about May (DOY 168 186) in 2015 and April (DOY 132-139) in 2016, with the fastest growth rate varying between 14.4 and $18.2 \mu \mathrm{m} \mathrm{day}^{-1}$ in 2015 and between 18.1 and $19.6 \mu \mathrm{m} \mathrm{day}^{-1}$ in 2016 (Fig. 2). After that, the rate of xylem formation began to decline gradually and entered a slow-growth period in late November to December (Fig. 2). The difference in timing of the growth peaks between the 2 years (May in 2015 and April in 2016) may be caused by the varied climate conditions among different years.

\subsection{Effect of $\mathbf{N}$ addition on the dynamics of xylem formation}

Xylem formation was well-fitted with a Gompertz function (Table 2), with $R^{2}$ varying from 0.91 to 0.96 in the different treatments. In 2015, the average widths of the xylem rings in the $\mathrm{CK}$ and $\mathrm{CN}$ trees were $1.58 \mathrm{~mm}$ and $1.91 \mathrm{~mm}$, respectively. In 2016, the average widths were $1.95 \mathrm{~mm}$ and $2.33 \mathrm{~mm}$, respectively (Table 2). During the 2 years, the modeled width of xylem rings were larger in $\mathrm{CN}$ than in $\mathrm{CK}$ trees (Fig. 2), and the addition of $\mathrm{N}$ increased widths by $21 \%$ in 2015 and $20 \%$ in 2016. During the early growth season (from February to May in 2015 and from February to April in 2016), the widths of the xylem rings (Table 3) and rates of growth (Fig. 3) were significantly higher in the $\mathrm{CN}$ trees than in the $\mathrm{CK}$ trees. In contrast, during the late growth season (from June to December in 2015 and from May to December in 2016), the width of xylem rings (Table 3 ) and the rates of growth did not differ between the two groups (Fig. 3).

Table 4 in the Appendix shows how the significance of the effects of $\mathrm{N}$ addition, DOY, and the interaction of $\mathrm{N}$ addition and DOY differed among cell types, between stages of the growth seasons, and between years. As Table 4 in the Appendix shows, the effect of $\mathrm{N}$ addition was significant on the following items: width of the cambium cells during early and late growth seasons in 2016, enlarging cells during the early growth seasons, wall-thickening cells during the early growth season only in 2015, and the mature cells in both the early and late growth seasons in 2015 but only in the early growth season in 2016. Furthermore, Table 4 in the Appendix shows that the interaction effect of $\mathrm{N}$ addition and DOY was not significant on the width of the cambium cells, enlarging cells, or wall-thickening cells but only on the mature cells in the early growth seasons in 2015 and 2016. 
Fig. 1 Width of cell layers in cambial zone (a), width of zones with enlarging cells (b), wallthickening cells (c), and mature cells (d) in 2015 and 2016. Dots represent the observed mean of the radial width of the cambial and differentiating xylem cells in trees in $\mathrm{CK}$ and $\mathrm{CN}$. Bars represent standard errors of the mean of the radial width of the cambial and differentiating xylem cells in trees in $\mathrm{CK}$ and $\mathrm{CN}$. CK and $\mathrm{CN}$ represent control and $\mathrm{N}$ treated trees, respectively
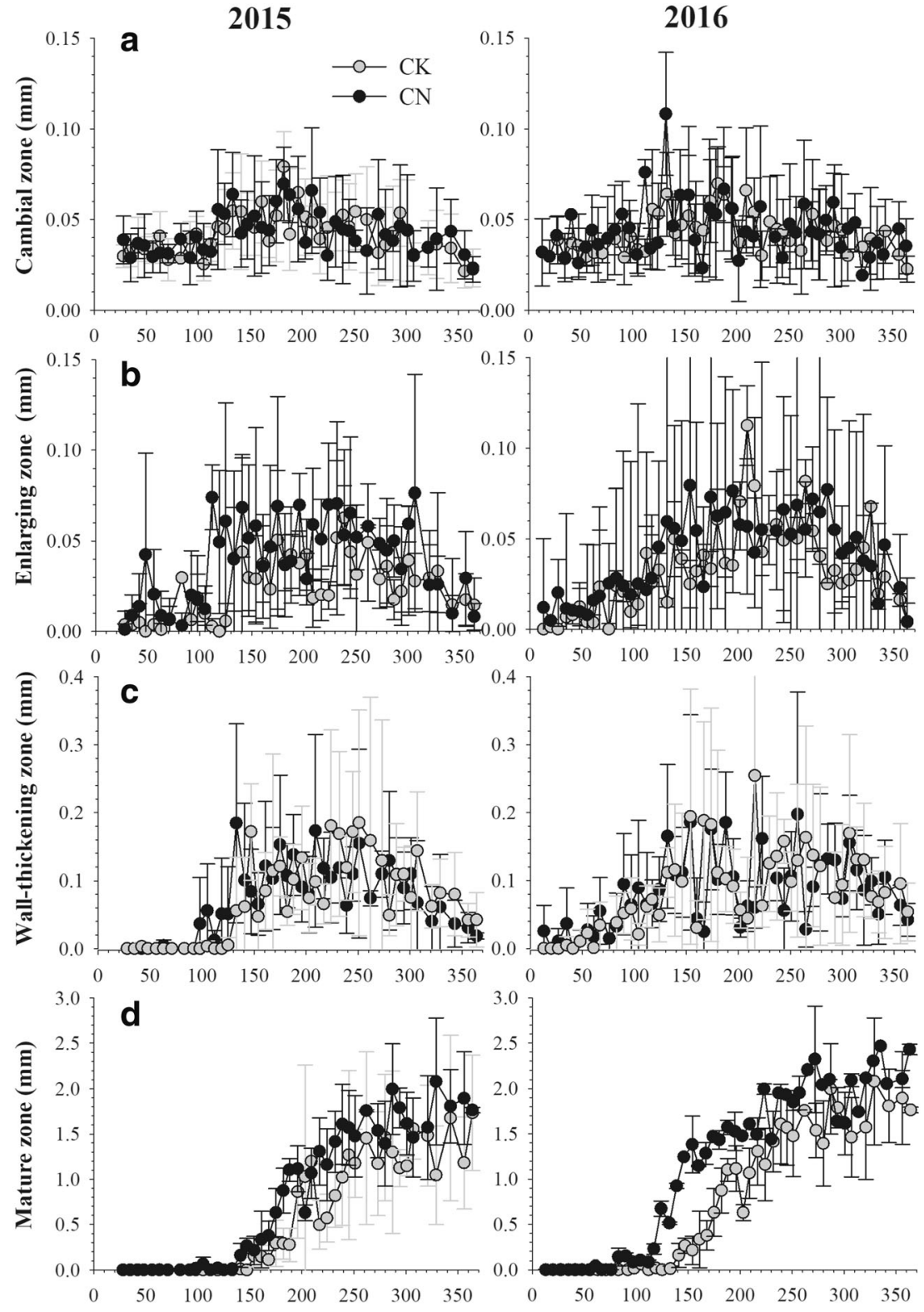

Day of the year

\section{Discussion}

In this study, our results showed that $\mathrm{N}$ deposition promoted xylem formation of $C$. chinensis in subtropical forests. In fact, $\mathrm{N}$ can be absorbed by fine roots in the soil or by the leaves, microbes, and lichen in the canopy (Sievering et al. 2007; Talhelm et al. 2011; Wang et al. 2014). According to Gaige et al. (2007), $70 \%$ of added $\mathrm{N}$ can be intercepted by the canopy of dominant tree species, and the absorbed $\mathrm{N}$ can easily be used by the leaves to influence tree growth. Xylem formation depends largely on the supply of nonstructural carbon (Nakaji et al. 2001), which is closely associated with photosynthesis. In a previous experiment in this study area, Liu et al. (2018) found that $\mathrm{N}$ addition increased the concentrations of $\mathrm{N}$ and chlorophyll in the leaves of $C$. chinensis, which can promote photosynthesis (Reich et al. 1997) and further stimulate xylem formation. During 2013 and 2014, an increased accumulation of $\mathrm{N}$ and carbohydrates in the $\mathrm{CN}$ treatment group may have been stored and remobilized to promote tree growth in the following years (Babst and Coleman 2018; Canovas et al. 2018). This explains why in 2015 and 2016, the effects of $\mathrm{N}$ addition on xylem 
Fig. 2 Modeled xylem ring width and growth rate of $C$. chinensis in CK and CN in 2015 (left panel) and 2016 (right panel). Based on observed xylem ring width (mm), Gompertz function was used to simulate the intra-annual xylem growth pattern of $C$. chinensis and its derivate was calculated as the growth rate $(\mu \mathrm{m} /$ day). Black dots and red dots represent observed xylem width in $\mathrm{CK}$ and $\mathrm{CN}$, respectively. The black line and the red line represent simulated xylem width in $\mathrm{CK}$ and $\mathrm{CN}$, respectively. $\mathrm{CK}$ and $\mathrm{CN}$ represent control and $\mathrm{N}$-treated trees
2015

2016
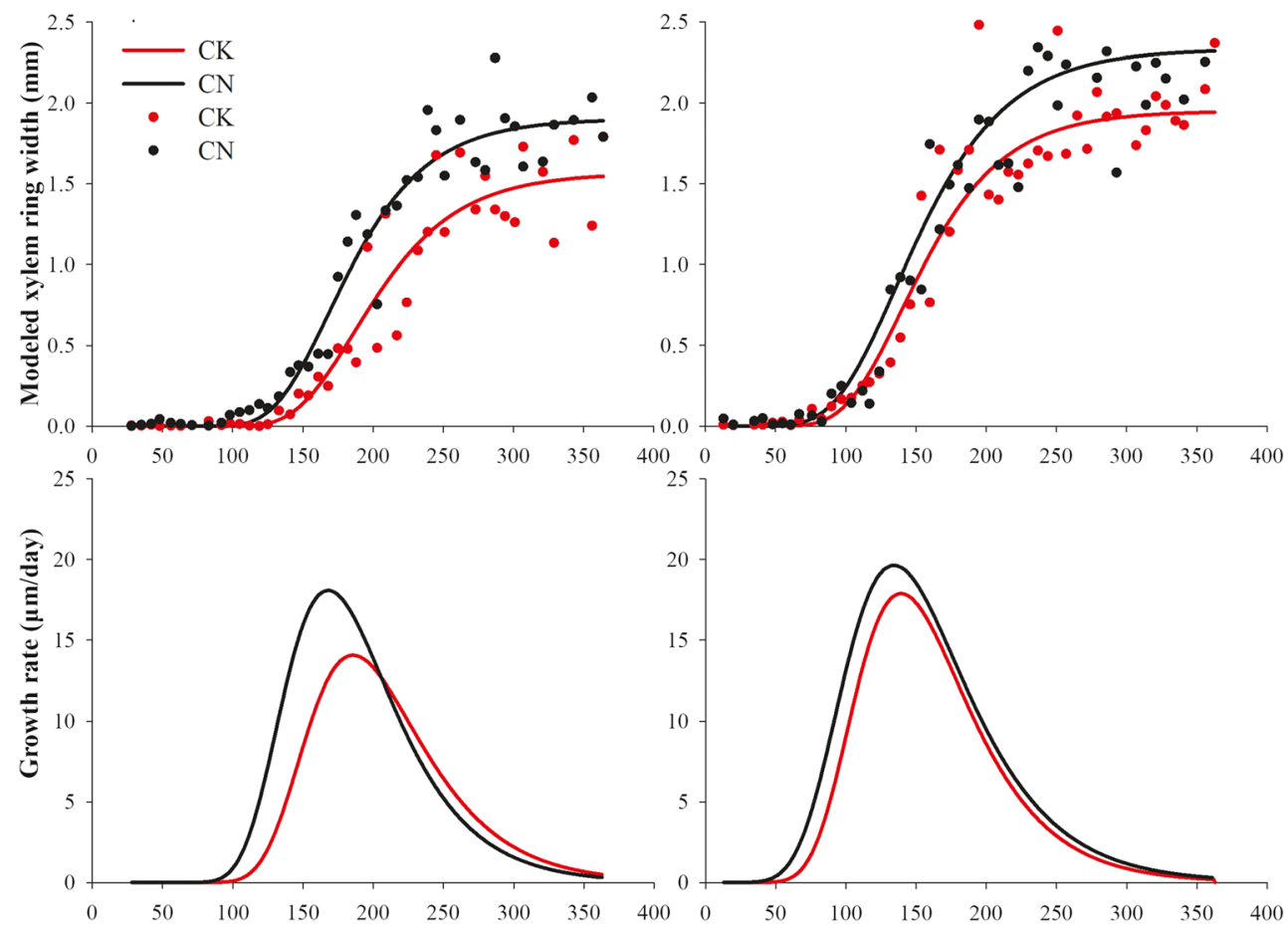

Day of the year formation was observed in February, before the beginning of $\mathrm{N}$ addition in April.

In fact, the effect of $\mathrm{N}$ addition on tree growth was nonlinear, with moderate $\mathrm{N}$ addition promoting tree growth and excess $\mathrm{N}$ addition reducing plant growth (Mo et al. 2008; Wang et al. 2018). Other researchers have observed decreased tree growth when adding $\mathrm{N}$ at levels that exceed tree demand (Kula et al. 2012). In addition, previous studies applied $\mathrm{N}$ on the forest floor, ignoring the important $\mathrm{N}$ interception by the canopy (Gaige et al. 2007; Adriaenssens et al. 2012). In subtropical forests, highly weathered soil displays a limited ability to retain $\mathrm{N}$. During the wet season in particular, added $\mathrm{N}$ will be flushed out by abundant precipitation (Fang et al. 2009).
Thus, traditional $\mathrm{N}$ addition experiments may underestimate the effect of $\mathrm{N}$ deposition on tree growth.

In addition, by dividing the entire growth season into two phases, our study demonstrated that the effect of $\mathrm{N}$ deposition on xylem formation was significant only during the early part of the growth season. This may be caused by a series of important physiological processes involved in tree growth at that time. For example, the formation of tracheids, especially those having large vessels, and an abundant supply of carbohydrates are crucial for tree growth. More $\mathrm{N}$ addition benefits vessel formation and photosynthesis (Samuels et al. 2006; Nakaji et al. 2001), thus promoting tree growth. The results of the present study indicate that the effect of $\mathrm{N}$ addition on
Table 2 Parameters (A, $\left.\beta, k, T_{\mathrm{p}}\right)$ and $R^{2}$ of the Gompertz functions applied to weekly radial growth under two treatments in 2015 and 2016. $A, \beta, k$, and $T_{\mathrm{p}}$ represent the upper asymptote, the $x$-axis placement, the change rate of the curve, and the day of maximum growth date, respectively. DOY represents the day of year. CK and CN represent control and $\mathrm{N}$-treated trees

\begin{tabular}{lllllrr}
\hline Year & Treatment & $A(\mu \mathrm{m})$ & $\beta$ & $k\left(10^{-2}\right)$ & $T_{\mathrm{p}}(\mathrm{DOY})$ & $R^{2}$ \\
\hline 2015 & $\mathrm{CK}$ & $1576.554 \pm 94.523$ & $4.795 \pm 0.934$ & $2.576 \pm 0.512$ & $181 \pm 5$ & $0.916 \pm 0.042$ \\
& $\mathrm{CN}$ & $1909.132 \pm 62.252$ & $4.464 \pm 0.602$ & $2.621 \pm 0.343$ & $168 \pm 3$ & $0.964 \pm 0.021$ \\
2016 & $\mathrm{CK}$ & $1951.814 \pm 61.134$ & $3.577 \pm 0.827$ & $2.554 \pm 0.623$ & $139 \pm 3$ & $0.932 \pm 0.033$ \\
& $\mathrm{CN}$ & $2334.321 \pm 80.412$ & $3.169 \pm 0.721$ & $2.932 \pm 0.545$ & $134 \pm 4$ & $0.923 \pm 0.026$ \\
\hline
\end{tabular}


Table 3 Effect of $\mathrm{N}$ on xylem ring width and growth rate during early growth season (February to May in 2015 and February to April in 2016) and late growth season (June to December in 2015 and May to December in 2016). T represents the effect of $\mathrm{N}$ addition; $\mathrm{D}$ represents the effect of $\mathrm{DOY} ; \mathrm{T} \times \mathrm{D}$ represents the interaction effect of $\mathrm{N}$ addition and DOY. DOY represents the day of year

\begin{tabular}{|c|c|c|c|c|c|c|}
\hline & \multirow[t]{2}{*}{ Phase } & \multirow[t]{2}{*}{ Effect } & \multicolumn{2}{|l|}{ Year 2015} & \multicolumn{2}{|l|}{ Year 2016} \\
\hline & & & $F$ & $P$ & $F$ & $P$ \\
\hline \multirow[t]{6}{*}{ Xylem width } & \multirow[t]{3}{*}{ Early } & $\mathrm{T}$ & 44.550 & $<0.001$ & 15.781 & $<0.001$ \\
\hline & & $\mathrm{D}$ & 525.331 & $<0.001$ & 589.182 & $<0.001$ \\
\hline & & $\mathrm{T} \times \mathrm{D}$ & 61.742 & $<0.001$ & 17.190 & $<0.001$ \\
\hline & \multirow[t]{3}{*}{ Late } & $\mathrm{T}$ & 0.615 & 0.433 & 3.061 & 0.082 \\
\hline & & $\mathrm{D}$ & 1635.723 & $<0.001$ & 1286.332 & $<0.001$ \\
\hline & & $\mathrm{T} \times \mathrm{D}$ & 0.051 & 0.821 & 3.281 & 0.074 \\
\hline \multirow[t]{6}{*}{ Growth rate } & \multirow[t]{3}{*}{ Early } & $\mathrm{T}$ & 54.012 & $<0.001$ & 14.862 & $<0.001$ \\
\hline & & $\mathrm{D}$ & 1137.091 & $<0.001$ & 1401.469 & $<0.001$ \\
\hline & & $\mathrm{T} \times \mathrm{D}$ & 37.500 & $<0.001$ & 3.922 & 0.048 \\
\hline & \multirow[t]{3}{*}{ Late } & $\mathrm{T}$ & 0.043 & 0.836 & 1.683 & 0.195 \\
\hline & & $\mathrm{D}$ & 2850.324 & $<0.001$ & 1955.191 & $<0.001$ \\
\hline & & $\mathrm{T} \times \mathrm{D}$ & 0.181 & 0.671 & 0.000 & 0.995 \\
\hline
\end{tabular}

xylem formation varies during the growth season. Compared with interannual measurement of stem growth, the method used in our study enabled a more precise understanding of the effect of $\mathrm{N}$ deposition on tree growth. More studies are needed on the seasonal effect of $\mathrm{N}$ deposition on plant growth.

Boreal and temperate forests are mainly $\mathrm{N}$-limited ecosystems in which $\mathrm{N}$ deposition can promote tree growth by meeting trees' demands for $\mathrm{N}$ (Hattenschwiler et al. 1996). In contrast, given that subtropical forests are N-rich but P-limited ecosystems (Penuelas et al. 2013), excessive $\mathrm{N}$ deposition may induce soil acidification and nutrient imbalance, thereby inhibiting tree growth and forest productivity (Matson et al. 1999; Lu et al. 2014). Contrary to our hypothesis, the positive effect of 4-year $\mathrm{N}$ addition on xylem formation indicates that $\mathrm{N}$ addition can still promote tree growth in N-rich subtropical forests. In another tropical forest in south China near our study site, $72 \%$ of added

${ }^{15} \mathrm{~N}$ tracer was recovered in the plants and soil (Gurmesa et al. 2016). In addition, according to a global metaanalysis, $75 \%$ of added ${ }^{15} \mathrm{~N}$ tracer was found in temperate forest ecosystems (Templer et al. 2012). That proportion of retained $\mathrm{N}$ resembles the proportions detected in subtropical forests (Gurmesa et al. 2016), indicating that even under different $\mathrm{N}$ deposition backgrounds, a similar $\mathrm{N}$-cycling mechanism may exist to regulate tree growth in response to $\mathrm{N}$ deposition.

\section{Conclusions}

Our study provides a novel, precise assessment of the effect of short-term $\mathrm{N}$ addition on xylem formation in subtropical forest trees. The stimulating effects of $\mathrm{N}$ addition on tree growth resemble those observed in N-limited boreal and temperate forests, suggesting the possibility that tree xylem growth in subtropical forests may still be sensitive to $\mathrm{N}$ deposition and may continue to benefit from increased $\mathrm{N}$ deposition in the future. Nevertheless, because the present study is based on the 2-year monitoring of a single species, we recommend long-term experiments regarding the effects of $\mathrm{N}$ deposition on xylem formation in more diverse species in tropical-subtropical regions to increase the understanding of how forest ecosystems would respond to future global changes.
Fig. 3 Effects of canopy N addition on averaged growth rate of C. chinensis during the early and late growth season in CK and $\mathrm{CN}$ in 2015 (left panel) and 2016 (right panel). The black bar and the gray bar represent averaged growth rate. $\mathrm{CK}$ and $\mathrm{CN}$ represent control and $\mathrm{N}$-treated trees. $* * *$ indicates significance at $P<0.001$
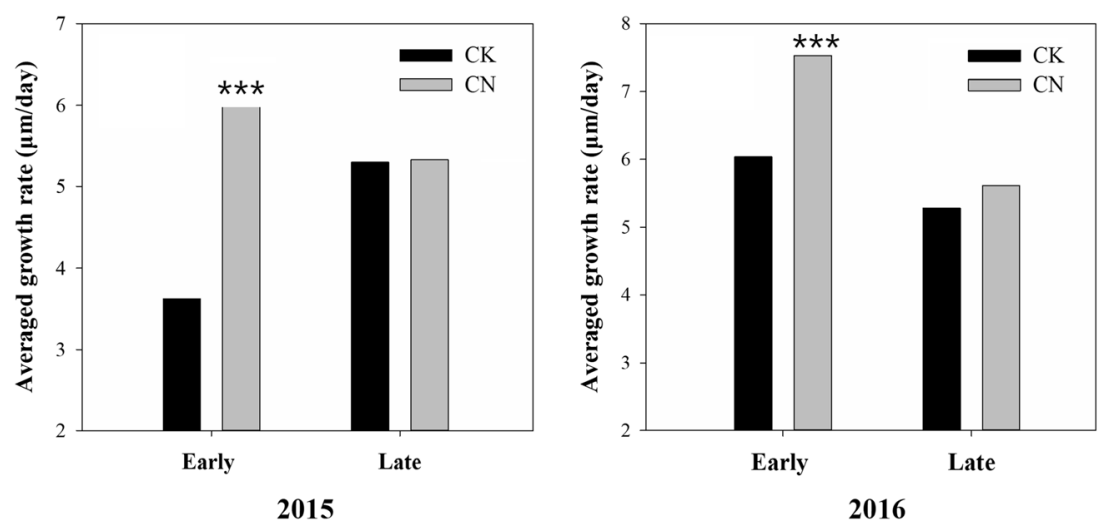
Acknowledgments The authors thank Zhiyuan He, Yuanqiu Li, and Zhibei Huang for sampling. We also thank Shimengtai National Natural Reserve for providing logistical assistance.

Funding information This project was supported by the National Natural Science Foundation of China (Grant Nos. 31570584, 41661144007, 41861124001, 31600392, 41701047, and 31901166), the Natural Science Foundation of Guangdong Province (2019B121202007, 2016A030310013), the International Collaborative Key Project of the CAS (GJHZ1752), the Key Special Project for Introduced Talents Team of Southern Marine Science and Engineering Guangdong

\section{Appendix}

Table 4 Comparison of cambial cells and differentiating cells in C. chinensis between two treatments (control and $\mathrm{N}$-treated trees) using repeated measures ANOVA during early and late growth seasons in 2015 and 2016. T represents the effect of $\mathrm{N}$ addition; D represents the effect of
Laboratory (Guangzhou) (GML2019ZD0408), and the China Postdoctoral Science Foundation (Grant No. 2018 M643227).

Data availability The datasets generated and/or analyzed during the current study are available in the FigShare repository (https://doi.org/10. 6084/m9.figshare.11923026.v3).

\section{Compliance with ethical standards}

Conflict of interest The authors declare that they have no conflicts of interest.

\begin{tabular}{|c|c|c|c|c|c|c|c|c|c|}
\hline \multirow[t]{2}{*}{ Cell types } & \multirow[t]{2}{*}{ Effect } & \multicolumn{2}{|c|}{ Year 2015 (E) } & \multicolumn{2}{|c|}{ Year 2015 (L) } & \multicolumn{2}{|c|}{ Year 2016 (E) } & \multicolumn{2}{|c|}{ Year 2016 (L) } \\
\hline & & $F$ & $P$ & $F$ & $P$ & $F$ & $P$ & $F$ & $P$ \\
\hline \multirow[t]{3}{*}{ Cambium } & $\mathrm{T}$ & 0.008 & 0.931 & 0.281 & 0.596 & 4.119 & 0.044 & 9.451 & 0.002 \\
\hline & $\mathrm{D}$ & 25.168 & $<0.001$ & 7.950 & 0.005 & 1.564 & 0.213 & 0.348 & 0.556 \\
\hline & $\mathrm{T} \times \mathrm{D}$ & 2.166 & 0.144 & 2.866 & 0.092 & 1.511 & 0.221 & 0.093 & 0.761 \\
\hline \multirow[t]{3}{*}{ Enlarging cells } & $\mathrm{T}$ & 7.434 & 0.007 & 2.900 & 0.090 & 6.096 & 0.015 & 1.735 & 0.189 \\
\hline & $\mathrm{D}$ & 23.501 & $<0.001$ & 2.523 & 0.114 & 7.695 & 0.015 & 2.737 & 0.098 \\
\hline & $\mathrm{T} \times \mathrm{D}$ & 1.055 & 0.306 & 0.154 & 0.695 & 0.626 & 0.430 & 0.064 & 0.800 \\
\hline \multirow[t]{3}{*}{ Wall-thickening cells } & $\mathrm{T}$ & 2.472 & 0.119 & 0.191 & 0.663 & 4.203 & 0.042 & 2.993 & 0.085 \\
\hline & $\mathrm{D}$ & 4.323 & 0.040 & 0.436 & 0.510 & 3.706 & 0.056 & 1.504 & 0.221 \\
\hline & $\mathrm{T} \times \mathrm{D}$ & 2.471 & 0.119 & 0.326 & 0.569 & 0.820 & 0.366 & 0.711 & 0.400 \\
\hline \multirow[t]{3}{*}{ Mature cells } & $\mathrm{T}$ & 9.288 & 0.002 & 4.658 & 0.032 & 7.072 & $<0.001$ & 0.258 & 0.612 \\
\hline & $\mathrm{D}$ & 7.341 & 0.007 & 15.564 & $<0.001$ & 20.450 & $<0.001$ & 2.013 & 0.157 \\
\hline & $\mathrm{T} \times \mathrm{D}$ & 19.052 & $<0.001$ & 1.854 & 0.175 & 6.288 & 0.013 & 2.801 & 0.095 \\
\hline
\end{tabular}

DOY; $\mathrm{T} \times \mathrm{D}$ represents the interaction effect of $\mathrm{N}$ addition and DOY; $\mathrm{E}$ represents early growth season (February to May in 2015 and February to April in 2016); L represents late growth season (June to December in 2015 and May to December in 2016). DOY represents the day of year 


\section{References}

Aber JD (1992) Nitrogen cycling and nitrogen saturation in temperate forest ecosystems. Trends Ecol Evol 7:220-224. https://doi.org/10. 1016/0169-5347(92)90048-G

Abe H, Funada R, Ohtani J, Fukazawa K (1997) Changes in the arrangement of cellulose microfibrils associated with the cessation of cell expansion in tracheids. Trees-Structure and Function 11:328-332. https://doi.org/10.1007/s004680050092

Adriaenssens S, Staelens J, Wuyts K, Van Wittenberghe S, Wuytack T, Verheyen K, Boeckx P, Samson R (2012) Canopy uptake of ${ }^{15} \mathrm{NH}_{3}$ by four temperate tree species and the interaction with leaf properties. Water Air Soil Pollut 223:5643-5657. https://doi.org/10.1007/ s11270-012-1304-4

Babst BA, Coleman GD (2018) Seasonal nitrogen cycling in temperate trees: transport and regulatory mechanisms are key missing links. Plant Sci 270:268-277. https://doi.org/10.1016/j.plantsci.2018.02. 021

Bauer GA, Bazzaz FA, Minocha R, Long S, Magill A, Aber J, Berntson GM (2004) Effects of chronic N additions on tissue chemistry, photosynthetic capacity, and carbon sequestration potential of a red pine (Pinus resinosa Ait.) stand in the NE United States. For Ecol Manag 196:173-186. https://doi.org/10.1016/j.foreco.2004.03.032

Bobbink R, Hicks K, Galloway J, Spranger T, Alkemade R, Ashmore M, Bustamante M, Cinderby S, Davidson E, Dentener F, Emmett B, Erisman JW, Fenn M, Gilliam F, Nordin A, Pardo L, De Vries W (2010) Global assessment of nitrogen deposition effects on terrestrial plant diversity: a synthesis. Ecol Appl 20:30-59. https://doi.org/ 10.1890/08-1140.1

Canovas FM, Canas RA, de la Torre FN, Pascual MB, Castro-Rodriguez $\mathrm{V}$, Avila C (2018) Nitrogen metabolism and biomass production in forest trees. Front Plant Sci 9. https://doi.org/10.3389/fpls.2018. 01449

D'Orangeville L, Cote B, Houle D, Morin H, Duchesne L (2013) A threeyear increase in soil temperature and atmospheric $\mathrm{N}$ deposition has minor effects on the xylogenesis of mature balsam fir. TreesStructure and Function 27:1525-1536. https://doi.org/10.1007/ s00468-013-0899-4

Dail DB, Hollinger DY, Davidson EA, Fernandez I, Sievering HC, Scott NA, Gaige E (2009) Distribution of nitrogen-15 tracers applied to the canopy of a mature spruce-hemlock stand, Howland, Maine, USA. Oecologia 160:589-599. https://doi.org/10.1007/s00442009-1325-x

Dao MCE, Rossi S, Walsh D, Morin H, Houle D (2015) A 6-year-long manipulation with soil warming and canopy nitrogen additions does not affect xylem phenology and cell production of mature black spruce. Front Plant Sci 6. https://doi.org/10.3389/fpls.2015.00877

Deslauriers A, Morin H, Begin Y (2003) Cellular phenology of annual ring formation of Abies balsamea in the Quebec boreal forest (Canada). Canadian Journal of Forest Research-Revue Canadienne De Recherche Forestiere 33:190-200. https://doi.org/10.1139/x02178

Fang Y, Gundersen P, Mo J, Zhu W (2009) Nitrogen leaching in response to increased nitrogen inputs in subtropical monsoon forests in southern China. For Ecol Manag 257:332-342. https://doi.org/10.1016/j. foreco.2008.09.004

Gaige E, Dail DB, Hollinger DY, Davidson EA, Fernandez IJ, Sievering H, White A, Halteman W (2007) Changes in canopy processes following whole-forest canopy nitrogen fertilization of a mature spruce-hemlock forest. Ecosystems 10:1133-1147. https://doi.org/ 10.1007/s10021-007-9081-4

Galloway JN, Dentener FJ, Capone DG, Boyer EW, Howarth RW, Seitzinger SP, Asner GP, Cleveland CC, Green PA, Holland EA, Karl DM, Michaels AF, Porter JH, Townsend AR, Vorosmarty CJ
(2004) Nitrogen cycles: past, present, and future. Biogeochemistry 70:153-226. https://doi.org/10.1007/s10533-004-0370-0

Galloway JN, Townsend AR, Erisman JW, Bekunda M, Cai Z, Freney JR, Martinelli LA, Seitzinger SP, Sutton MA (2008) Transformation of the nitrogen cycle: recent trends, questions, and potential solutions. Science 320:889-892. https://doi.org/10.1126/science. 1136674

Gricar J, Cufar K, Oven P, Schmitt U (2005) Differentiation of terminal latewood tracheids in silver fir during autumn. Ann Bot 95:959-965. https://doi.org/10.1093/aob/mci112

Gruber A, Oberhuber W, Wieser G (2018) Nitrogen addition and understory removal but not soil warming increased radial growth of Pinus cembra at treeline in the central Austrian Alps. Front Plant Sci:9. https://doi.org/10.3389/fpls.2018.00711

Guo XL, Huang JG, Li JY, Liang HX, Yu BY, Ma QQ, Jiang SW, Lu $\mathrm{XK}, \mathrm{Fu} \mathrm{SL}, \mathrm{Ye} \mathrm{Q}$, Zhao P, Cai XN (2020) Nitrogen addition to canopy promotes xylem formation of Castanopsis chinensis (Sprengel) Hance in a subtropical forest in China. V3. FigShare. [Dataset]. https://doi.org/10.6084/m9.figshare.11923026.v3

Gurmesa GA, Lu X, Gundersen P, Mao Q, Zhou K, Fang Y, Mo J (2016) High retention of N-15-labeled nitrogen deposition in a nitrogen saturated old-growth tropical forest. Glob Chang Biol 22:36083620. https://doi.org/10.1111/gcb.13327

Hattenschwiler S, Schweingruber FH, Korner C (1996) Tree ring responses to elevated $\mathrm{CO} 2$ and increased $\mathrm{N}$ deposition in Picea abies. Plant Cell Environ 19:1369-1378. https://doi.org/10.1111/j.13653040.1996.tb00015.x

Huang J-G, Guo X, Rossi S, Zhai L, Yu B, Zhan S, Zhang M (2018) Intra-annual wood formation of subtropical Chinese red pine shows better growth in dry season than wet season. Tree Physiol 38:12251236. https://doi.org/10.1093/treephys/tpy046

Huang L, Zhu W, Ren H, Chen H, Wang J (2012) Impact of atmospheric nitrogen deposition on soil properties and herb-layer diversity in remnant forests along an urban-rural gradient in Guangzhou, southern China. Plant Ecol 213:1187-1202. https://doi.org/10.1007/ s11258-012-0080-y

Kula E, Pešlová A, Martinek P (2012) Effects of nitrogen on growth properties and phenology of silver birch (Betula pendula Roth). J For Sci 58:391-399. https://doi.org/10.1016/0169-5347(92)90048$\mathrm{G}$

Liu N, Wu S, Guo Q, Wang J, Cao C, Wang J (2018) Leaf nitrogen assimilation and partitioning differ among subtropical forest plants in response to canopy addition of nitrogen treatments. Sci Total Environ 637:1026-1034. https://doi.org/10.1016/j.scitotenv.2018. 05.060

Liu X, Zhang Y, Han W, Tang A, Shen J, Cui Z, Vitousek P, Erisman JW, Goulding K, Christie P, Fangmeier A, Zhang F (2013) Enhanced nitrogen deposition over China. Nature 494:459-462. https://doi. org/10.1038/nature11917

Lovett GM, Lindberg SE (1993) Atmospheric deposition and canopy interactions of nitrogen in forests. Canadian Journal of Forest Research-Revue Canadienne De Recherche Forestiere 23:16031616. https://doi.org/10.1139/x93-200

Lu X, Mao Q, Gilliam FS, Luo Y, Mo J (2014) Nitrogen deposition contributes to soil acidification in tropical ecosystems. Glob Chang Biol 20:3790-3801. https://doi.org/10.1111/gcb.12665

Lu X, Mo J, Gilliam FS, Yu G, Zhang W, Fang Y, Huang J (2011) Effects of experimental nitrogen additions on plant diversity in tropical forests of contrasting disturbance regimes in southern China. Environ Pollut 159:2228-2235. https://doi.org/10.1016/j.envpol.2010.10. 037

Lu X, Vitousek PM, Mao Q, Gilliam FS, Luo Y, Zhou G, Zou X, Gilliamd FS, Hou E, Mo J (2018) Plant acclimation to long-term high nitrogen deposition in an N-rich tropical forest. Proceedings of the National Academy of Sciences, 115:5187-5192. https://doi.org/ 10.1073/pnas.1720777115 
Lupi C, Morin H, Deslauriers A, Rossi S, Houle D (2012) Increasing nitrogen availability and soil temperature: effects on xylem phenology and anatomy of mature black spruce. Canadian Journal of Forest Research-Revue Canadienne De Recherche Forestiere 42:12771288. https://doi.org/10.1139/x2012-055

MacDonald JA, Dise NB, Matzner E, Armbruster M, Gundersen P, Forsius $M$ (2002) Nitrogen input together with ecosystem nitrogen enrichment predict nitrate leaching from European forests. Glob Chang Biol 8:1028-1033. https://doi.org/10.1046/j.1365-2486. 2002.00532.x

Matson PA, McDowell WH, Townsend AR, Vitousek PM (1999) The globalization of $\mathrm{N}$ deposition: ecosystem consequences in tropical environments. Biogeochemistry 46:67-83. https://doi.org/10.1023/ a: 1006152112852

Mo J, Brown S, Xue J, Fang Y, Li Z (2006) Response of litter decomposition to simulated $\mathrm{N}$ deposition in disturbed, rehabilitated and mature forests in subtropical China. Plant Soil 282:135-151

Mo J, Li D, Gundersen P (2008) Seedling growth response of two tropical tree species to nitrogen deposition in southern China. Eur J For Res 127:275-283. https://doi.org/10.1007/s10342-008-0203-0

Nakaji T, Fukami M, Dokiya Y, Izuta T (2001) Effects of high nitrogen load on growth, photosynthesis and nutrient status of Cryptomeria japonica and Pinus densiflora seedlings. Trees-Structure and Function 15:453-461. https://doi.org/10.1007/s00468-001-0130-x

Penuelas J, Poulter B, Sardans J, Ciais P, van der Velde M, Bopp L, Boucher O, Godderis Y, Hinsinger P, Llusia J, Nardin E, Vicca S, Obersteiner M, Janssens IA (2013) Human-induced nitrogen-phosphorus imbalances alter natural and managed ecosystems across the globe. Nat Commun:4. https://doi.org/10.1038/ncomms3934

R Core Team (2018) R: a language and environment for statistical computing. R Foundation for statistical computing, Vienna. Available: http://www.r-project.org/

Rathgeber CBK, Rossi S, Bontemps J-D (2011) Cambial activity related to tree size in a mature silver-fir plantation. Ann Bot 108:429-438. https://doi.org/10.1093/aob/mcr168

Reich PB, Walters MB, Ellsworth DS (1997) From tropics to tundra: global convergence in plant functioning. Proc Natl Acad Sci U S A 94:13730-13734. https://doi.org/10.1073/pnas.94.25.13730

Rose CL (1996) Forest canopy atmosphere interactions. Northwest Sci 70:7-14

Rossi S, Anfodillo T, Menardi R (2006) Trephor: a new tool for sampling microcores from tree stems. IAWA J 27:89-97. https://doi.org/10. $1163 / 22941932-90000139$

Sala OE, Chapin FS, Armesto JJ, Berlow E, Bloomfield J, Dirzo R, Huber-Sanwald E, Huenneke LF, Jackson RB, Kinzig A, Leemans R, Lodge DM, Mooney HA, Oesterheld M, Poff NL, Sykes MT, Walker BH, Walker M, Wall DH (2000) Biodiversity - global biodiversity scenarios for the year 2100. Science 287:1770-1774. https://doi.org/10.1126/science.287.5459.1770

Samuels AL, Kaneda M, Rensing KH (2006) The cell biology of wood formation: from cambial divisions to mature secondary xylem. Canadian Journal of Botany-Revue Canadienne De Botanique 84: 631-639. https://doi.org/10.1139/b06-065

Sievering H, Tomaszewski T, Torizzo J (2007) Canopy uptake of atmospheric $\mathrm{N}$ deposition at a conifer forest: part I - canopy $\mathrm{N}$ budget, photosynthetic efficiency and net ecosystem exchange. Tellus Series B-Chemical and Physical Meteorology 59:483-492. https://doi.org/ 10.1111/j.1600-0889.2007.00264.x

Talhelm AF, Pregitzer KS, Burton AJ (2011) No evidence that chronic nitrogen additions increase photosynthesis in mature sugar maple forests. Ecol Appl 21:2413-2424. https://doi.org/10.1890/10-2076.

Templer PH, Mack MC, Chapin FS III, Christenson LM, Compton JE Crook HD, Currie WS, Curtis CJ, Dail DB, D'Antonio CM, Emmett BA, Epstein HE, Goodale CL, Gundersen P, Hobbie SE, Holland K, Hooper DU, Hungate BA, Lamontagne S, Nadelhoffer KJ, Osenberg CW, Perakis SS, Schleppi P, Schimel J, Schmidt IK, Sommerkorn M, Spoelstra J, Tietema A, Wessel WW, Zak DR (2012) Sinks for nitrogen inputs in terrestrial ecosystems: a metaanalysis of N-15 tracer field studies. Ecology 93:1816-1829. https:// doi.org/10.1890/11-1146.1

Wang A, Fang YT, Chen DX, Koba K, Makabe A, Li YD, Luo TS, Yoh M (2014) Variations in nitrogen-15 natural abundance of plant and soil systems in four remote tropical rainforests, southern China. Oecologia 174:567-580. https://doi.org/10.1007/s00442-0132778-5

Wang M, Zhang WW, Li N, Liu YY, Zheng XB, Hao GY (2018) Photosynthesis and growth responses of Fraxinus mandshurica Rupr. seedlings to a gradient of simulated nitrogen deposition. Annals of Forest Science, 75: 1. https://doi.org/10.1007/s13595017-0678-2

Yu GR, Chen Z, Piao SL, Peng CH, Ciais P, Wang QF, Li XR, Zhu XJ (2014) High carbon dioxide uptake by subtropical forest ecosystems in the East Asian monsoon region. Proc Natl Acad Sci U S A 111: 4910-4915. https://doi.org/10.1073/pnas.1317065111

Yu B, Huang JG, Ma Q, Guo X, Liang H, Zhang S et al (2019) Comparison of the effects of canopy and understory nitrogen addition on xylem growth of two dominant species in a warm temperate forest, China. Dendrochronologia 56:125604. https://doi.org/10. 1016/j.dendro.2019.125604

Zhang S, Huang J-G, Rossi S, Ma Q, Yu B, Zhai L, Luo D, Guo X, Fu S, Zhang W, Tognetti R (2017) Intra-annual dynamics of xylem growth in Pinus massoniana submitted to an experimental nitrogen addition in Central China. Tree Physiol. https://doi.org/10.1093/ treephys/tpx079:1-8

Zhang S, Rossi S, Huang J-G, Jiang S, Yu B, Zhang W, Ye Q (2018) Intra-annual dynamics of xylem formation in Liquidambar formosana subjected to canopy and understory $\mathrm{N}$ addition. Front Plant Sci:9. https://doi.org/10.3389/fpls.2018.00079

Zhang W, Shen W, Zhu S, Wan S, Luo Y, Yan J, Wang K, Liu L, Dai H, Li P, Dai K, Zhang W, Liu Z, Wang F, Kuang Y, Li Z, Lin Y, Rao X, Li J, Zou B, Cai X, Mo J, Zhao P, Ye Q, Huang J, Fu S (2015) Can canopy addition of nitrogen better illustrate the effect of atmospheric nitrogen deposition on forest ecosystem? Sci Rep 5. https:// doi.org/10.1038/srep11245

Publisher's note Springer Nature remains neutral with regard to jurisdictional claims in published maps and institutional affiliations. 


\section{Affiliations}

Xiali Guo ${ }^{1,2,3,4} \cdot$ Jian-Guo Huang ${ }^{1,2,3} \cdot$ Jingye $\mathrm{Li}^{1,2,3,4} \cdot$ Hanxue Liang ${ }^{1,2,3} \cdot$ Biyun $\mathrm{Yu}^{1,2,3,4} \cdot$ Qianqian Ma ${ }^{1,2,3}$. Shaowei Jiang ${ }^{1,2,3,4} \cdot$ Xiankai $\mathrm{Lu}^{1,2,3} \cdot$ Shenglei Fu ${ }^{5} \cdot$ Qing Ye ${ }^{1,2} \cdot$ Ping Zhao $^{1,2,3} \cdot$ Xian Cai $^{1,2,3}$

1 Key Laboratory of Vegetation Restoration and Management of Degraded Ecosystems, South China Botanical Garden, Chinese Academy of Sciences, 723 Xingke Road, Tianhe District, Guangzhou 510650, China

2 Center of Plant Ecology, Core Botanical Garden, Chinese Academy of Sciences, 723 Xingke Road, Tianhe District, Guangzhou 510650, China
3 Guangdong Provincial Key Laboratory of Applied Botany, South China Botanical Garden, Chinese Academy of Sciences, 723 Xingke Road, Tianhe District, Guangzhou 510650, China

4 University of Chinese Academy of Sciences, 19(A) Yuquan Road, Shijingshan District, Beijing 100049, China

5 Key Laboratory of Geospatial Technology for the Middle and Lower Yellow River Regions, Ministry of Education, College of Environment and Planning, Henan University, Kaifeng 475004, China 